Nunt. Antiquus, Belo Horizonte, v. 15, n. 1, p. 249-278, 2019

\title{
The Making of Merovingian Paris: The Christianization of a Gallo-Roman City
}

\author{
O Fazer-se da Paris Merovíngia: \\ a cristianização de uma cidade galo-romana
}

\author{
Tomás Pessoa ${ }^{1}$ \\ Universidade Federal Fluminense (UFF), Niterói, Rio de Janeiro / Brasil \\ tomasap@superig.com.br
}

\begin{abstract}
The present paper intends to analyze the Christianization of the city of Paris and its growing importance in the Merovingian period. The article begins with an introduction of the context of the Gallo-Roman city and the transformations that happened during the final centuries of the Roman Empire. In the third section, the Merovingian Paris will be examined (6th-7th centuries), specifically its three most important churches. Finally, in the final section of the paper, the process on which Paris, a relatively unimportant city at a regional level until the sixth century, became one of the most important cities in Merovingian Gaul will be explained. The consolidation of the Merovingian royal power and the Christianization of the city were part of the same process.
\end{abstract}

Keywords: Paris; Merovingians; Christian City.

Resumo: O presente trabalho pretende analisar a cristianização da cidade de Paris e sua crescente importância no período merovíngio. $\mathrm{O}$ artigo começa com uma introdução sobre o contexto da cidade galo-romana e as transformações que ocorreram durante os últimos séculos do Império Romano. Na terceira seção, a Paris Merovíngia será considerada (VI-VII d.C.), especificamente suas três mais importantes igrejas. Finalmente, na seção final, será explicado o processo pelo qual Paris, uma cidade relativamente sem importância em nível regional até aquele momento, transformou-se em uma das mais importantes cidades na Gália Merovíngia. A consolidação do poder real merovíngio e a cristianização da cidade foram partes de um mesmo processo.

Palavras-chave: Paris; Merovíngios; Cidade Cristã.

\footnotetext{
${ }^{1}$ Bolsista FAPERJ.
} 


\section{Introduction: From Lutetia to Paris}

The first reference to Gallic Lutetia, an oppidum ${ }^{2}$ located on an island in the Seine River, can be found in the De Bello Gallico written by the Roman general Julius Caesar (100-44 AD). The Parisii, the Gaulish inhabitants of Lutetia, were defeated by a Roman legion and, after this battle, Caesar's army eventually conquered all Gaul (BUSSON, 1998, p. 55). It was only during the reign of Augustus (27 BC-14 BC) and his successor Tiberius (14 AD-37 AD), however, that the province of Gaul was effectively organized by the Roman State. ${ }^{3}$

One of the most important changes in the areas conquered by Rome was the organization of the region by the erection of a great number of cities. Among many aspects of Roman life, the Roman city was particularly related to their way of living. According to the Roman senatorial discourse, in opposition to the barbarians, which were similar to animals, the Romans lived in cities, that is, they lived in the correct way in which a human being should live. ${ }^{4}$ By dominating the ones they considered barbarians, the Romans thought that it was possible for the conquered to achieve their full potential as human-beings, escaping the bestial condition of living like a barbarian (WOOLF, 1998, p. 57-59). This is the process long known by scholars as "Romanization". 5

\footnotetext{
${ }^{2}$ Oppidum was a Latin word used by Ceasar to refer to some of the biggest defended settlements acting as tribal centers in Gaul. Today the term is used to indicate large fortified settlements constructed in the end of the La Tène period (La Tène D $-1^{\text {st }}$ century BC). For more information about the oppida see Woolf (1993) and Fichtl (2007, p. 323-325). The oppidum of Lutetia was on an island on the Seine River, but, it is no longer certain that it was in the actual Île de la Cité. Although scholars since the sixteenth century held that position, Busson (1998, p. 55-61) demonstrated that this cannot be proved by the actual state of the excavations.

${ }^{3}$ To more about the Roman city of this period see Edmondson (2006, p. 250-280).

${ }^{4}$ For more about Senatorial Roman discourse, normally what can be seen through the written sources, and their image of the ones called barbarians see Woolf (2011).

${ }^{5}$ Contrary to what was previously thought, the "Romanization" didn't erase the Gaulish culture. Instead, when the two cultures entered in contact a new one was created, now called the Gallo-roman culture. We can observe how the Gallo-Roman culture was unique, for example, by offering the example of the Pilier des Nautes (Pilar of the Boatmen),
} 
The city was connected to specific architectural elements and festival/ceremonies that symbolized the union of the territory of which the city was the center and the union of all the cities of the Empire. Some of these most characteristic elements of the Roman architecture were present into the Gallo-Roman Lutetia: a Forum, a Theater, an Amphitheater and three Roman Thermae (Thermes de Gay-Lussac, Thermes du Collège de France and Thermes de Cluny, all named after their current location in the city of Paris). ${ }^{6}$ This was a city of approximately 100 ha and its center was established at the left bank of the Seine River while the actual Ile de la Cité and the right bank of the Seine were peripheral quarters (BUSSON, 1998, p. 63-66) (see Figure 1). ${ }^{7}$ We can also mention that following the tendency of the majority of Gallo-roman cities, built in the period of the Pax Romana, walls were not erected around Lutetia.

All these constructions and other changes associated with the Roman domination were not imposed violently. However, there was an indirect influence on the local elites. Among different motives, they realized that they could have a series of advantages from Roman domination. Consequently, in an effort to look roman so that they could beneficiate inside the structure of the Roman State, the local elites utilized their own resources to build the elements considered vital to the Roman city that we mentioned above. If a community failed to demonstrate the urban status which all these elements provided, its condition as a city could be questioned. On the other hand, by showing their condition as civilized human beings, the members of the local aristocracy could

composed of both Gaulish and Roman heroes and gods. For more about the critics to the concept of "Romanization" and the Gallo-Roman culture see Woolf (1998, p. 1-23). To see more about the Pilier des Nautes see Busson (1998, p. 447-452).

${ }^{6}$ The majority of these monuments was discovered by one of the greatest names of the archaeology of the city of Paris: Théodore Vacquer (1824-1899). His writings and drawings of the findings are still very important to the researchers today. To see more about T. Vacquer: Jones (2007). To see more about these Roman monuments: Busson (1998, p. 92-182).

${ }^{7}$ The urban periphery (or peri-urban area) was a recognized entity in the Roman world, distinguished from the urban and rural. For more about it see Goodman (2007). 
achieve different posts in the Roman State structure or have their city become a municipium or colonia (in the Western provinces of the Roman Empire), cities that won the right to have their own charter and selfgovernment (WOOLF, 1998, p. 71-72).

The constructions were financed by the Curia in which local aristocrats exerted their power and the membership was lifelong and in practice hereditary. One of the functions of the Curia was the collection of the taxes destined to the Roman State from the region of which the city was the capital. Nevertheless, the Curia also had the power to collect taxes and rents associated, for example, with sales in the city and leased public spaces. In addition, there were also resources derived from the voluntary donations related to aristocratic prestige competition, especially the amount paid by the aristocrats when they entered the curia, the summa honoraria (DEY, 2015, p. 26-28). With those resources, the curia could finance and pay for the maintenance of all the elements aforementioned associated with the Roman city.

All of this demonstrates that in the period of the High Roman Empire $\left(1^{\text {st }}-3^{\text {rd }} A D\right)$, the Roman State didn't have an extensive and centralized administration and it depended on other mechanisms to ensure the domination and taxation of the provinces. This situation started to change in the $3^{\text {rd }}$ century. 
FIGURE 1 - The City of Lutetia in the period of the High Roman Empire.

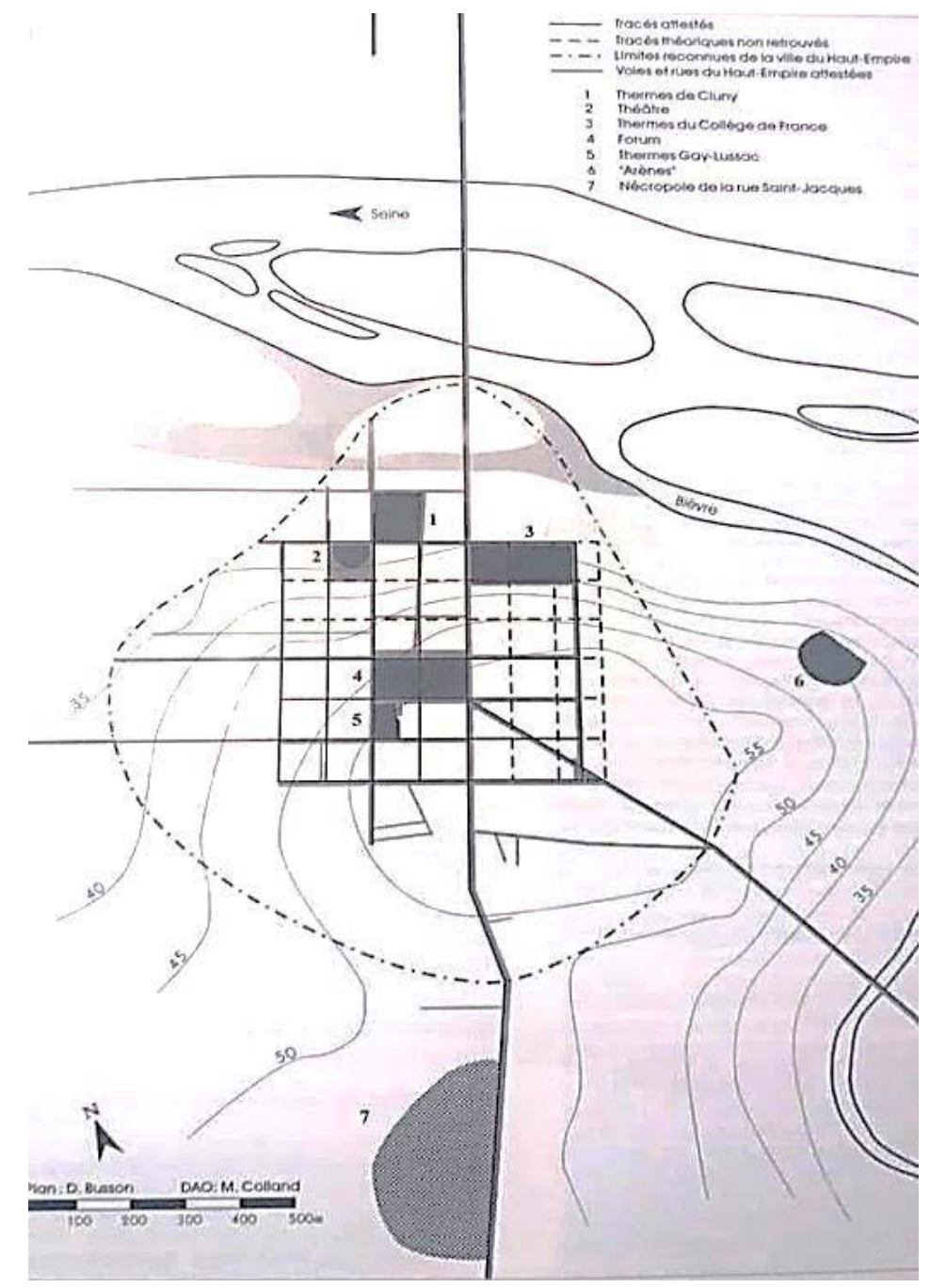

Caption: 1- Thermes de Cluny; 2- Theater; 3- Thermes du Collège de France; 4- Forum; 5- Thermes de Gay-Lussac; 6- Amphitheater; 7- Cemetery of St. Jacques street.

Source: Busson, 1998, p. 67.0 
The so-called third-century crisis didn't affect all the Roman provinces, but it did disturb the province of Gaul especially since the 250 's. ${ }^{8}$ In particular, we can mention here that the Roman Emperor Gallienus (253-268 AD) had to secure different frontiers of the Roman Empire from attacks of Germanic ethnic groups or usurpations and, eventually, Gaul was left unprotected from the invasions of Alemanni and Franks between 255 and 260. Gallienus arrived in Gaul to stop the attacks in 256, but left only two years later to protect the Danubian frontier. These difficulties led to the usurpation of Postumus (260-8 AD) and the creation of the Gallic empire until the Battle of Châlons (274 AD) when Gaul was annexed again to the Roman Empire by the Roman Emperor Aurelianus (270-275AD). In the next year, however, this emperor was killed and once again Gaul was invaded by Franks and Alemanni. In the aftermath of the last invasions, local groups called Bagaudes revolted and also started a series of pillages in the center, north, and east of the Gallic province.

In light of all these events, it is no wonder that Lutetia was affected. It is possible to observe from the excavations that perhaps fires occurred and abandonment of some of the previously occupied areas of the city (actual rue de Pierre-et-Marie Curie; northern part of actual boulevard Saint-Michel) and public monuments such as the Thermes de Gay-Lussac and Thermes de Cluny took place (BUSSON, 1998, p. 76, 182; BOUET et al., 2008, p. 396). At the beginning of the $4^{\text {th }}$ century, following a general tendency of the cities of Northern Gaul, the city began to be called after the old Gaulish inhabitants of the region and eventually the name Paris supplanted Lutetia (DUVAL, 1989, p. 910). ${ }^{9}$

\footnotetext{
${ }^{8}$ The period from the murder of Alexander Severus (235) to the rise of Diocletian (284) is known in the Roman History as "Anarchy" and it is characterized by a great number of emperors and the murder of practically all of them. In a period of crescent importance of the army in Roman politics, the Emperors, from that moment on, were normally from the army and needed especially the military support to govern. To see more about the third-century crisis: Potter (2006, p. 153-166) and Modéran (2006, p. 19-60).

${ }^{9}$ According to Rouche (2003, p. 14-26), during the period of the High Roman Empire, the cities of Northern Gaul had an official name, but also a local name related to the inhabitants of the region. That being the case, the invasions, the Gallic Empire and the weakening of the Roman power in the region of Northern Gaul are probably related
} 


\section{The new center of Paris in the $4^{\text {th }}$ century: The Île de la Cité}

As a result of the difficulties of the third century, Diocletian (284-305 AD) assumed the government and initiated a series of reforms that gradually led to a centralization of the Roman State. Some of the most relevant in the context of this study were the significant growth of the Roman Army to face the new threats of the $3^{\text {rd }}$ and $4^{\text {th }}$ century, such as the new Germanic confederations and the Sassanid Persian Empire, and a reorganization and division of the provinces in a way that their number was eventually doubled. ${ }^{10}$ In each one of these new provinces, a governor and a great number of functionaries chosen by the emperor were established. Besides, the old provinces were also divided in twelve dioceses, each one with a commanding vicar, with his own administrative personnel, which responded to the Praetorian Prefect (DEY, 2015, p. 25 ). All these changes greatly increased the taxation and consequently, a great burden was put on the local aristocracies related to the curia. If they were not capable of attending the minimum demands of the State, they could be punished physically or have their own properties confiscated (LIEBESCHUETZ, 1992, p. 7).

Given the new demands on the curia, the membership became onerous to the local aristocracies. First, those with more resources among the local aristocracies started to avoid the curia and concentrate on more interesting options such as the many new posts in the imperial administration created by the reforms of Diocletian. That brought a series of advantages. First, they were given the title of a senator (depending on the post it could even bring the title of illustris, the highest among the senators in the fourth century), which conferred great prestige, certainly bigger than the curia. Second, they were exempted of the curia's responsibilities and received their payment in the golden

to the change of names. The local name began to appear, even in the official sources, in the end of the third century in this region. More specifically in the case of Paris, the first references of the change of name are present in the writings of the Roman Emperor Julian (360-3 AD) and of Ammianus Marcellinus (c. 325-c. 391). Among many other examples in Northern Gaul, we can mention here the city of Caesarnudum which was eventually called Tours because of the Gaulish Turoni.

${ }^{10}$ To Diocletian's reforms: Potter (2006, p. 166-170) and Modéran (2006, p. 69-92). 
solidi, the only stable coin of the time. Therefore, both in prestige and in economic security the members of the curia suffered great losses (LIEBESCHUETZ, 1992, p. 8; WICKHAM, 2005, p. 597).

Considering these facts, certainly, the curia was not very attractive after Diocletian's reforms, however, at the beginning of the fourth century they still possessed the prerogative to collect the local taxes as we mentioned above. There are discussions among the historians about what happened, but the direct consequence that interests us here is that, in the course of the fourth century, even most of those resources were passed to the Roman State (DEY, 2015, p. 28). ${ }^{11}$ As a consequence of this, the Curia didn't have the resources to build and keep the maintenance of the monuments and other elements associated with the Roman city of the period of the High Roman Empire. At that moment this was a responsibility of the governors chosen by the emperors.

The governors and other members of the imperial administration were privileged and could invest in their home cities if they wanted to. However, that was not what normally happened because they had different interests. Their actions were concentrated in the imperial capitals, places where their monuments would be seen by more people and would guarantee more prestige and recognition by the emperors (who could indicate them to new imperial posts). Consequently, in capital cities like Trier, Milan, Constantinople, Antioch and Thessaloniki new magnificent monuments were built. The emperor and the members of the imperial administration had the intention of integrating them in the great power spectacle called adventus, a procession which celebrated the arrival of the emperor, a person with a particularly high administrative post or, later, a bishop (DEY, 2015, p. 31, 33-64).

In contrast to these capitals, in the small and medium GalloRoman cities, the monuments were not given constant maintenance and, as result, they became ruins and were used as a material of constructions for the new walls in the fourth century. The majority of cities in Gaul didn't have walls in the High Empire and, when they were constructed, normally they enclosed a smaller space than the city of the previous centuries. This fact may indicate depopulation related to the invasions

${ }^{11}$ For more about this see Delmaire (1989). 
and other difficulties of the third and fourth centuries, but it should not be exaggerated because the archaeological evidence indicates that many people could live outside the walls (LIEBESCHUETZ, 1992, p. 10).

This was also the case in Paris. Following the invasions of the third century, the current analysis demonstrates that the construction of the walls started in $308 \mathrm{AD}$ around the new center of the city, the actual Île de la Cité, and they were already completed by 360 AD. The abandonment of the left bank of the Seine that occurred in the third century was intensified in the fourth century and the material of ancient monuments, especially the amphitheater, was used to erect the walls (BUSSON, 1998, p. 384, 391-402). Nevertheless, once again it is important to emphasize that this area was not abandoned completely. There are traces of habitations in the left bank of the Seine in the fourth century and it was certainly less onerous to construct the walls around $10 \mathrm{ha}$, where at least part of the population could go in times of attacks, than the old center of approximately 100 ha (FLEURY; LEPROUX, 2002, p. 214-216). Besides the walls, the new center of the city was comprised of at least four monuments also erected in the fourth century: the basilica, the "Palais", one Roman thermae and the Cathedral (Figure 2).

The first one, the basilica, was constructed using material from the mausoleums of the cemetery from the period of the High Empire, but it is difficult to determine the function of this monument. Maybe it was a public square and/or a point of reunion of the new informal groups which eventually governed the city after the demise of the Curia, maybe it was also a center of economic importance, but none of this is certain (BUSSON, 1998, p. 415-416). The "Palais" was probably a military construction and it was presumably used as an imperial residence by the Roman Emperors Julian and Valentinian I (364-375 AD) while they lived in the city. This edifice was constructed in a very similar way to the Roman basilica, especially with the utilization of funerary monuments of the High Empire present in the left bank of the Seine (BUSSON, 1998, p. 384, 424). As for the third monument, Bouet et al. (2008, p. 396-400) demonstrated that this was a public therma. It is certainly smaller than the Gallo-Roman thermes of the previous centuries mentioned above, but considering other examples in Gaul on the Late Roman Empire, 
the authors came to the conclusion that the one in Paris was actually of medium size in comparison. ${ }^{12}$

FIGURE 2 - Paris in the period of the Late Roman Empire. It is important to point it out the Cathedral mentioned above was located below the actual Église de NotreDame and this is why it is referred by this name in the image. It is also important to remind that although the monuments of the left bank are indicated in this image, most of them probably were already abandoned at the beginning of the fourth century.

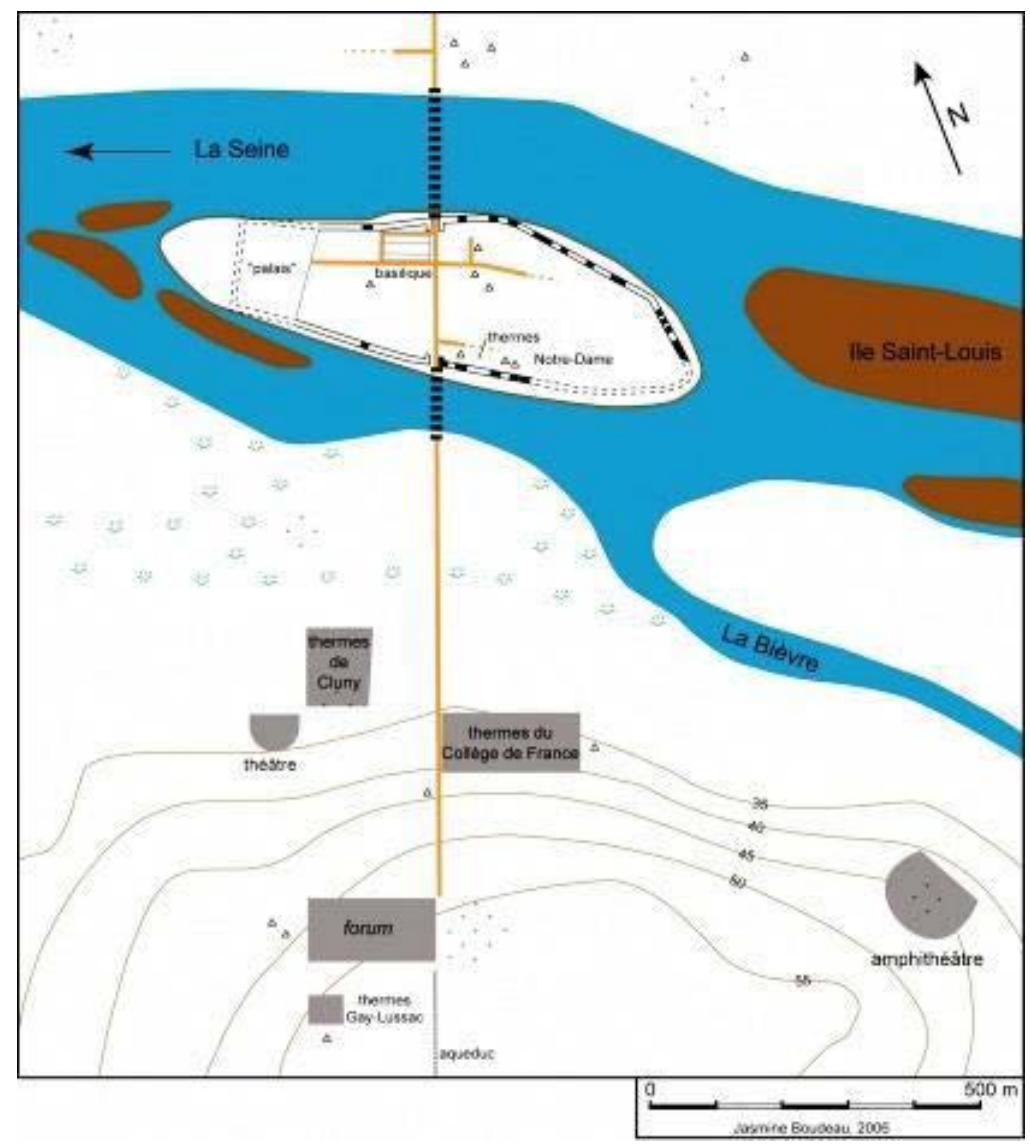

Source: Adapted from Boudeau (2011, p. 491).

\footnotetext{
${ }^{12}$ The Roman thermae in the Île de la Cité had approximately $102 \mathrm{~m}^{2}$ and it was bigger than the Roman thermae of Toulouse $\left(50 \mathrm{~m}^{2}\right)$ and Montferad $\left(62 \mathrm{~m}^{2}\right)$. It was evidently much smaller than the one in the imperial capital Trier $\left(7350 \mathrm{~m}^{2}\right)$ (BOUET et al., 2008, p. 399).
} 
The last monument referred above was very close to the ecclesia,${ }^{13}$ that is, the first church of Paris. Benefiting from the gradual decline of the Curia as explained above, a more restricted and informal group started to effectively govern the city. This group was composed of senators, the governor who had been chosen by the emperor, and gradually, the highest ecclesiastical hierarchy, the bishop (WICKHAM, 2005, p. 597579). Benefiting from the conversion of members of the aristocracy along the fourth century, many ecclesiae in Gaul were constructed with the bishops' initiatives. This was the case, for example, of Bishop Lidorius (337/8-371 AD) at Tours (GREGOIRE DE TOURS, 1999b, X, XXXI).

When we consider the example of Paris, there is written and archaeological evidence that the ecclesia of Paris was built in the fourth century. ${ }^{14}$ Still, there isn't much information about the bishops of Paris in the fourth century. ${ }^{15}$ Even the scanty information we can gather about Bishop Marcellus (c. 360-436), for example, is derived especially from his Life, written at least one hundred years after his episcopacy by Venantius Fortunatus (c. 530-600/9).

Concluding this section, what we would like to emphasize is that there are no abrupt ruptures between the Gallo-Roman city and the Christian city at Gaul. Some of the most characteristic GalloRoman monuments such as the Roman thermae and the basilica existed simultaneously to the Cathedral. This indicates that the changes in habits

\footnotetext{
${ }^{13}$ The word ecclesia is used by Gregory of Tours (c. 538-594) and Venantius Fortunatus (c. 530-600/609) to refer to the first church in each city of Gaul, normally constructed within the walls and where it was celebrated the Mass. The word basilica, on the other hand, was normally used to refer to the churches outside the city walls and normally housing saint's relics. For more about this see: Lorans (2007, p. 284-285). For more information about these two authors and all the other written sources presented in this article see: Cândido da Silva e Mazetto Júnior (2006). More specifically about Gregory see: Heinzelmann (2001).

${ }^{14}$ The ecclesia is mentioned on the Life of St. Martin written in 397 and marbles dated to the fourth century were found in the excavations (VIEILLARD-TROIEKOROUFF, 1976a, p. 204-205; BUSSON, 1998, p. 467-471).

${ }^{15}$ From the first bishops of Paris there is usually nothing but names and occasionally a register of participation in a council. For the episcopal lists of Paris see Duchesne (1910, p. 464-476).
} 
were very gradual on a daily basis. The inhabitants of Paris probably continued to go to the thermae and to the basilica while at the same time they attended the Cathedral to participate in the rituals associated with Christianity. In the next centuries, following the construction of more Christian buildings and the institution of festivals associated with different saints in the city of Paris, some of the Gallo-Roman monuments were eventually abandoned. Of course, the Cathedral was still very important in the Middle Ages and the "Palais" was used as a residence by the Merovingian kings (BUSSON, 1998, p. 386). However, we will consider in the next section the three most important churches of Paris of the next centuries: The Church of the Holy Apostles, The Church of Saint-Vincent and the Church of Saint-Denis.

\section{Merovingian Paris: Clovis I, Childebert I and Dagobert I}

In the context of the fifth century, especially in the aftermath of the invasions of Vandals, Suevi and Alans in 406, the bishops, normally from an important aristocratic family, gradually became the leaders of their cities in Gaul. This was a consequence of the difficulties experienced at Gaul in this century, especially from the pillages of the Germanic ethnic groups and local groups in Gaul. Given this background, as Brown (2013, p. 106-107) argued, walls and bishops became very related in the context of the defense of the urban citizens, such as it was the case of the resistance of Bishop Aignan (c. 358-453) in Orleans against the Huns in 451 or the defense of Clermont organized by Bishop Sidonius Apollinaris (c. 430-488) against the Visigoths between 471 and 474. They were capable of organizing the defense by keeping the moral of the citizens in the sense of communion offered by Christianity in a series of daily practices like processions and Masses associated with the ecclesiae already built.

Still, once again, there aren't many references about bishops of Paris in the fifth century. In sources that survived, the closest person in Paris which supposedly acted like a bishop in the fifth century was Saint Geneviève (c. 420-502/512), as it is written in the Life of Geneviève. 
Besides the threats posed by Attila, Paris was actually sieged by the Franks and Geneviève was apparently very important in keeping the moral of the inhabitants and traveling along the Seine to provide food for them during this period. It is also interesting to notice that the Frankish king and Roman governor of Belgica Secunda, Childeric (c. 436-481) at least was acquainted with Geneviève (ROUCHE, 1996, p. 470-473). ${ }^{16}$

Until this moment, the city of Paris perhaps had local importance due to its location on the Seine River, so it was chosen by emperors such as Julianus and Valentinianus as a residence, even briefly. Nevertheless, it seems that Paris was not one of the most important cities of Gaul. Even after the consecutive divisions of the provinces of the High Roman Empire in Gaul following Diocletian's reforms in the fourth century, Paris was still overshadowed by other cities such as Tours, Rouen and especially Sens, capitals of newly created provinces of Lugdunensis Secunda, Tertia and Senonia respectively. This would change in the sixth century because of the actions related to the son of Childeric I: Clovis (c. 481-511), the first Merovingian King.

Much has already been written about Clovis. ${ }^{17}$ Here we will briefly mention some of the most important events of his reign and especially his relation to Paris. After the death of his father in 481, Clovis inherited the throne and the position of Roman governor of the Belgica Secunda. In a moment where the majority of the Germanic kings were Arian Christians, Clovis married the Catholic Burgundian princess Clotilde. Maybe with her influence, he decided to be baptized to Nicene Christianity by Bishop Remigius (c. 437-533) in Reims at some point between the end of the fifth century and the beginning of the sixth century. ${ }^{18}$ Among all his military triumphs, Clovis' victory at the Battle

\footnotetext{
${ }^{16}$ For more about Childeric see Périn e Riché (1996, p. 89-95).

${ }^{17}$ For different analysis of Clovis see: Daly (1994); Rouche (1996). For the Merovingian period in general: Cândido da Silva (2008) and Freitas (2015).

${ }^{18}$ If we follow the dates provided by Gregory of Tours, the baptism happened in 496 after the victory in the battle of Tolbiac (496). Still, there are those who argue that it happened in 498 (ROUCHE, 1996, p. 272) and those who defend that it happened only in 508 (WOOD, 1994, p. 48).
} 
of Vouillé (507) against the Visigoths commanded by Alaric II (c. 458507) was probably the most important. After this event, Clovis managed to incorporate the great majority of Gaul to his kingdom and he chose Paris as his residence. At this moment, we will turn our attention to the principal monument constructed by the orders of Clovis in the city of Paris: The Church of the Holy Apostles.

According to Gregory of Tours (1999a, II, XLIII), the Church of the Holy Apostles of Paris began to be constructed by the orders of Clovis in the left bank of the Seine, however, it was only completely finished by his wife Clotilde, after the king's death in 511 (Figure 3). It is likely that Clovis constructed this Church in a direct reference to the Church of the Holy Apostles in Constantinople built by Constantine (306-337 AD), the first Roman Emperor to convert to Christianity. The image of "new Constantine" is used by Gregory of Tours in his writings and it is probable that Clovis perpetuated the comparison himself, but there is no clear evidence of the year in which the construction of the edifice began or when it was completed (GRÉGOIRE DE TOURS, 1999a, II, XXXI).

What we can know from the sources is that Clovis, his wife Clotilde, their daughter Clotilde and two of their grandsons were buried in this Church (GRÉGOIRE DE TOURS, 1999a, III, X, VI, 1). Importantly, Saint Geneviève's body was also buried in this Church at some point, probably after it had been buried in another important burial place in Paris (PÉRIN; RICHÉ, 1996, p. 110-112). Nevertheless, in the moment of construction of this Church the image of "New Constantine" that Clovis wanted to perpetuate overshadowed any relationship he might have had with Geneviève. ${ }^{19}$

Clovis' intention can also be seen in the architecture of the new Church. In the Life of Geneviève, we can observe a description of it. It had a triple porch and paintings of the patriarchs, prophets, martyrs, and a confessor. Soon after this passage, the author defends that in this

\footnotetext{
${ }^{19}$ It was only after the Merovingian period that the name of Geneviève overshadowed those of the Apostles and the name "Church of Saint-Geneviève" was established. See Lasteyrie (1887).
} 
place the Holy Trinity was particularly adored emphasizing the Nicene Creed (ROUCHE, 1996, p. 474). Following the argument proposed by Rouche (1996, p. 489-490), we can argue that the Church of the Holy Apostles was constructed as an affirmation of the orthodoxy against the heresy. The triple porch represented the three persons of the Holy Trinity and the painted figures probably depicted models of the orthodoxy such as Abraham and St. Martin. The Church of the Holy Apostles would certainly evoke Clovis' choice of orthodoxy against the Arianism providing yet another element of comparison between him and Constantine, legitimizing his rule of Gaul and constantly reminding everyone of his glorious victory at the Battle of Vouillé against the Arian Goths. ${ }^{20}$

If Clovis desired to establish the Church of the Holy Apostles of Paris as a royal mausoleum for the Merovingian Kingdom following the example of Constantine, his idea was not accepted by any of his sons because none of them were buried there. However, this building continued to be important as the siege of different important Church councils in the next centuries. In particular, the Council of Paris of 614 was assembled in there after a long period of civil wars. In the occasion, the victor Chlothar II (584-629) clearly wanted to evoke the figure of Clovis (his great-great-grandfather) as a symbol of union of Gaul for his new united kingdom. Clovis' memory was still strongly attached to the Church of the Holy Apostles.

${ }^{20}$ The connection of the battle and the church can already be seen in the eighth century (LIBER..., 17). 
FIGURE 3 - The city of Paris in the sixth century. The Church of Clovis is indicated by St. Apôtres while the church of St. Vincent is indicated by St. Vincent. Also depicted are the Church of St. Julien (St. Julien), the Church of St. Marcellus

(St. Marcel), an oratory of St. Martin and the Cathedral and its baptistery. ${ }^{21}$

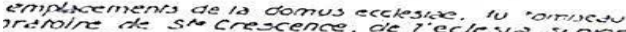
$\rightarrow$ Dasilica gonl inconnus.

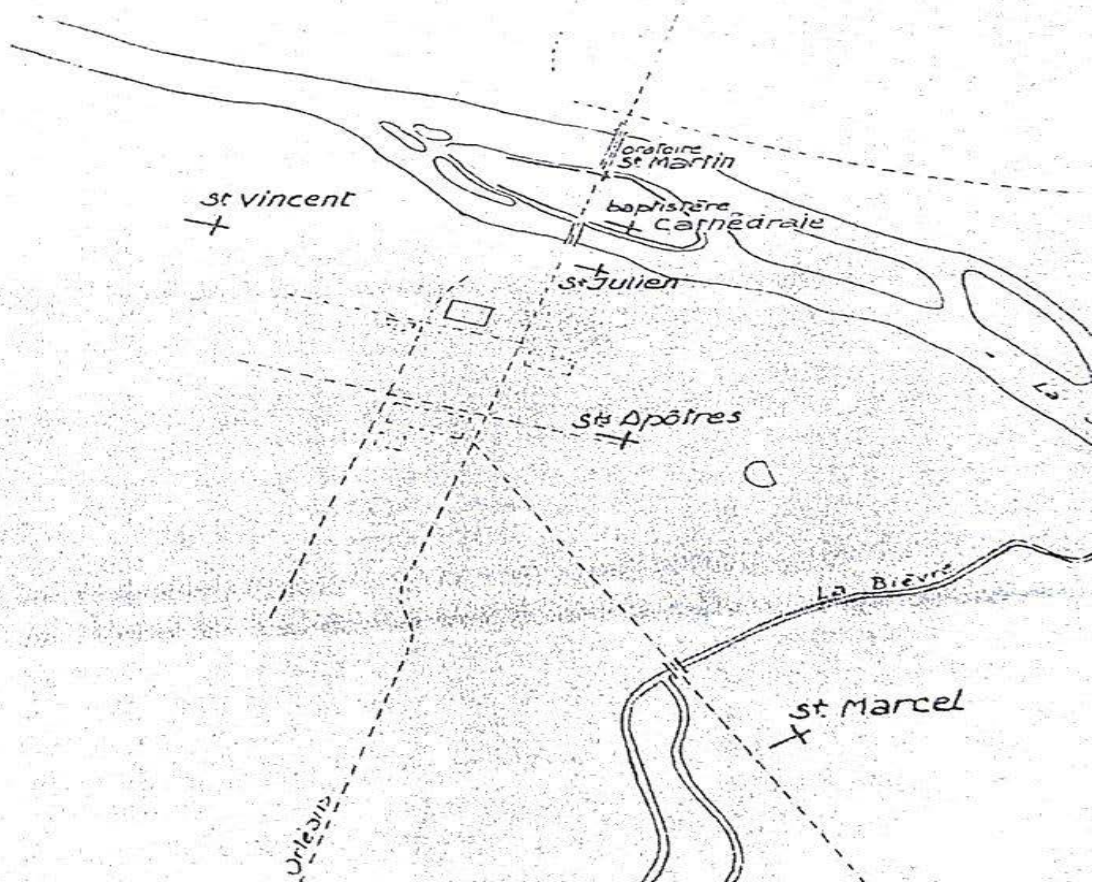

Source: Vieillard-Troiekorouff, 1976a, p. 203.

After Clovis' death, Gaul was divided into four parts and each one was governed by one of his sons: Theuderic I (511-534), Clodomir (511-524), Childebert I (511-558) and Chlothar I (511-561). Paris was the capital of the kingdom of Childebert I.

${ }^{21}$ To more about the Church of St. Julian and the Church of St. Marcellus see Busson (1998, p. 312, 376-378). 
Following the narrative tradition, in the year 541, Childebert I invaded the Iberian Peninsula and sieged the city of Zaragoza. After a procession of the population in the city, the local bishop gave to Childebert Saint Vincent's tunic. From this expedition Childebert also obtained a golden cross and, after his return to Paris, he donated them both to the new church that he ordered to be constructed and also where he was buried after his death in 558 (LIBER..., 26). According to the Life of Droctoveus, this Church probably had a cruciform plan. ${ }^{22}$ In each one of the four sides, an altar with a series of saint's relics existed. The most important altar was the eastern one which contained Saint Vincent's tunic and the Golden Cross. Therefore, the church was primarily known as the Church of Saint Vincent and Saint Cross and only in the twelfth century the name Saint-Germain-des-Prés was completely established thanks to Bishop Germanus of Paris (555-576) ${ }^{23} \mathrm{He}$ was buried in the chapel of St. Symphorien annexed to this Church after his death and in, the eighth century, his body was taken to the main building.

When we consider the fact that the Church of the Holy Apostles had already been built, we may wonder why didn't Childebert chose this place to be buried alongside his father. We believe that there is evidence on the works of Gregory of Tours that the narrative tradition mentioned was already established in the time of Childebert's death. ${ }^{24}$ Consequently,

\footnotetext{
${ }^{22}$ This Life was written in the eleventh century by a member of this Church, Gislemar. Even considering that this Church was destructed and reformed in the period between the eighth and tenth centuries, it is probable that Gislemar had documents which mentioned the format of the original Church constructed in the sixth century. Besides, a structure discovered in an excavation in Paris was identified as the south altar of the Church by T. Vacquer (DÉRENS, 1972; BUSSON, 1998, p. 353-354).

${ }^{23}$ This can be deduced from the charts conserved by this Church and present in the work of Poupardin (1909).

${ }^{24}$ We follow here the argument of Goffart (1998, p. 159-160). He argues that Gregory considered the History something confusing in which the acts of sinners were present alongside the saint's virtues. When we observe Gregory's Ten Books of History, we notice that his narrative is interrupted by many others which apparently have nothing to do with the first one. Only in the course of his narrative, Gregory turns back his attention to what he had started in the first place. The absence of details from the situations would be another mark of his conception of History. The expedition, Saint Vincent's tunic, the
} 
Childerbert's victorious military campaign, the relic he saved from the Arians Visigoths and the Church he made to house it would be part of that king's glorious deeds. What made this Church especial was its history.

In addition to the cruciform plan, it is possible that in this Church existed mosaics made of the byzantine tesserae technique (ERLANDEBRANDENBURG, 2011, p. 14-15). This technique involved the fitting together of small pieces of stone and glass (called tesserae) that, when set together, created a paint-like effect with different colors melding into each other and a sensation of depth. This technique had the additional advantage that glass and stone reflect the light in a way that normal paint can't. Moreover, the Byzantines also placed a gold backing behind the clear glass tesserae and the mosaics appeared to emit a mysterious light of their own (HURST, 2011). This technique can be seen, for example, in the mosaic of Emperor Justinian inside the Church of Saint Vitale of Ravenna. If this type of technique existed in the Church of Saint Vincent maybe Childebert I also wanted to surpass the Church of his father in terms of splendor and lavishness. This certainly would highlight even more his history and achievements. The success of the Church of Saint Vincent can be proved by the fact that this is the Church in which the greatest number of members from the Merovingian Royal Family was buried. $^{25}$

Finally, we will now consider Dagobert I (629-639), Clovis' great-great-grandson. His father, Chlothar II, had united all Gaul after a long period and he chose the city of Paris as his residence to rule and, finally, he chose to be buried in the Church of Saint Vincent mentioned above (FREDEGARIUS SCHOLASTICUS apud KRUSCH, 1888, IV, LVI). Dagobert succeeded his father as king of all Gaul from 629 until 639 and he also chose Paris as his residence, not in the "Palais" of Late

Church of St. Vincent of Paris and the fact that Childebert was buried in this Church are all cited by Tours (1999a, III, XXIX, IV, XX) The connection between all these elements, that is, the transference of the relic to the Church is just one of the many details that Gregory didn't think it was necessary to mention.

${ }^{25}$ For more about the Church of Saint Vincent and the Merovingian kings see Pessoa (2016, 2017). 
Roman Empire cited above, but in a palace in a region called Clichy, very close to Paris.

Although there are certainly doubts about its veracity, the document considered Dagobert's will clearly indicate that this king thought about being inhumed in the Church of Saint Vincent, which demonstrates the importance of this building because many other kings were buried there. Even if this was an interpolated copy of a previous manuscript, there was no point in inventing this tradition out of nothing, unless the author of this document was a member of the Church Saint Vincent, which it doesn't seem to be the case (ERLANDE-BRANDENBURG, 1975, p. 52). For some reason, however, Dagobert I changed his mind and he was eventually buried in the Church of Saint-Denis (Figure 4) (MEDIEVAL..., 2007, I, 33). ${ }^{26}$ This action is probably related to a great devotion to this saint which started at some point in his life.

The first references of inhumations in this Church can be found in the sixth century. There are two members of the royal family which were buried there: Arnegund (mother of Chilperic I (561-584)) and Dagobert (son of Chilperic I; not to be confused with the king of the seventh century) (GRÉGOIRE DE TOURS, 1999a, V, XXXIV). ${ }^{27}$ Still, clearly, the Church of Saint-Vincent was privileged over the Church of Saint-Denis considering the fact that the majority of Merovingian family members were buried there. As mentioned above, Dagobert I was the first king buried in Saint-Denis and, because of that, he made sure that this Church perpetuated his memory and erased the history of those who had been previously buried in there. We can observe how this was done by analyzing two written sources of the seventh century: The Chronicle of Fredegar and the Life of Eligius (WOOD, 1994, p. 248).

The first source mentions that Dagobert I "had magnificently ornamented (the Church) with gold, precious stones, and objects $[\ldots]$.

\footnotetext{
${ }^{26}$ According to the tradition, Saint Denis was the first bishop of Paris and he was martyred in approximately $250 \mathrm{AD}$ during the persecution of Christians established by Decius (GRÉGOIRE DE TOURS, 1999a, I, XXX).

${ }^{27}$ The tomb of Arnegund was found in an excavation in the second half of the twentieth century. See Périn (2009).
} 
He gives so many treasures to this Church [...] that many people are surprised" (FREDEGARIUS SCHOLASTICUS apud KRUSCH, 1888, IV, LXXIX). The second source mentions that Eligius, a skilled artisan, constructed:

$[\ldots]$ a mausoleum for the holy martyr Denis in the city of Paris with a wonderful marble ciborium over it marvelously decorated with gold and gems. He composed a crest [at the top of a tomb] and a magnificent frontal and surrounded the throne of the altar with golden axes in a circle. He placed golden apples there, round and jeweled. He made a pulpit and a gate of silver and a roof for the throne of the altar on silver axes. He made a covering in the place before the tomb and fabricated an outside altar at the feet of the holy martyr. So much industry did he lavish there, at the king's request, and poured out so much that scarcely a single ornament was left in Gaul and it is the greatest wonder of all to this very day. (MEDIEVAL..., 2007, I, 32). ${ }^{28}$

We can also mention the excavations organized by McKnight Crosby in 1937 from which he concluded that the building was aggrandized in many ways in the seventh century. He associated these actions to Dagobert I, even though scholars still have doubts about this (PÉRIN; RICHÉ, 1996, p. 296-7).

If we combine all these sources and the first charters of the Cartulaire Blanc attributed to Dagobert I, we can conclude that, if the Church of Saint-Denis wasn't very important, after these reforms and donations, it would have become a Church worthy of a king. ${ }^{29}$ With all the actions mentioned above related to the visual ornamentation of the

\footnotetext{
${ }^{28}$ For the Life of Eligius see note 25.

${ }^{29}$ The Cartulaire Blanc is the cartulary of the Church of Saint-Denis containing charters from the seventh to the fourteenth centuries. There are at least four charters attributed to Dagobert (two which are not suspected to be false) and they refer to donations to the Church of Saint-Denis. Available at: http://www.cn-telma.fr/originaux/resultat/. Accessed in: 19 sept. 2018.
} 
interior of the Church of Saint-Denis, it was possible for Dagobert to demonstrate all his power and the divine splendor of the place in which he would be buried. Given this background, it is not surprising that Clovis II (639-657/8), his son and successor, also chose to be buried in the Church of Saint-Denis.

FIGURE 4 - The road that connected the center of the city of Paris to the Church of Saint-Denis (in green).

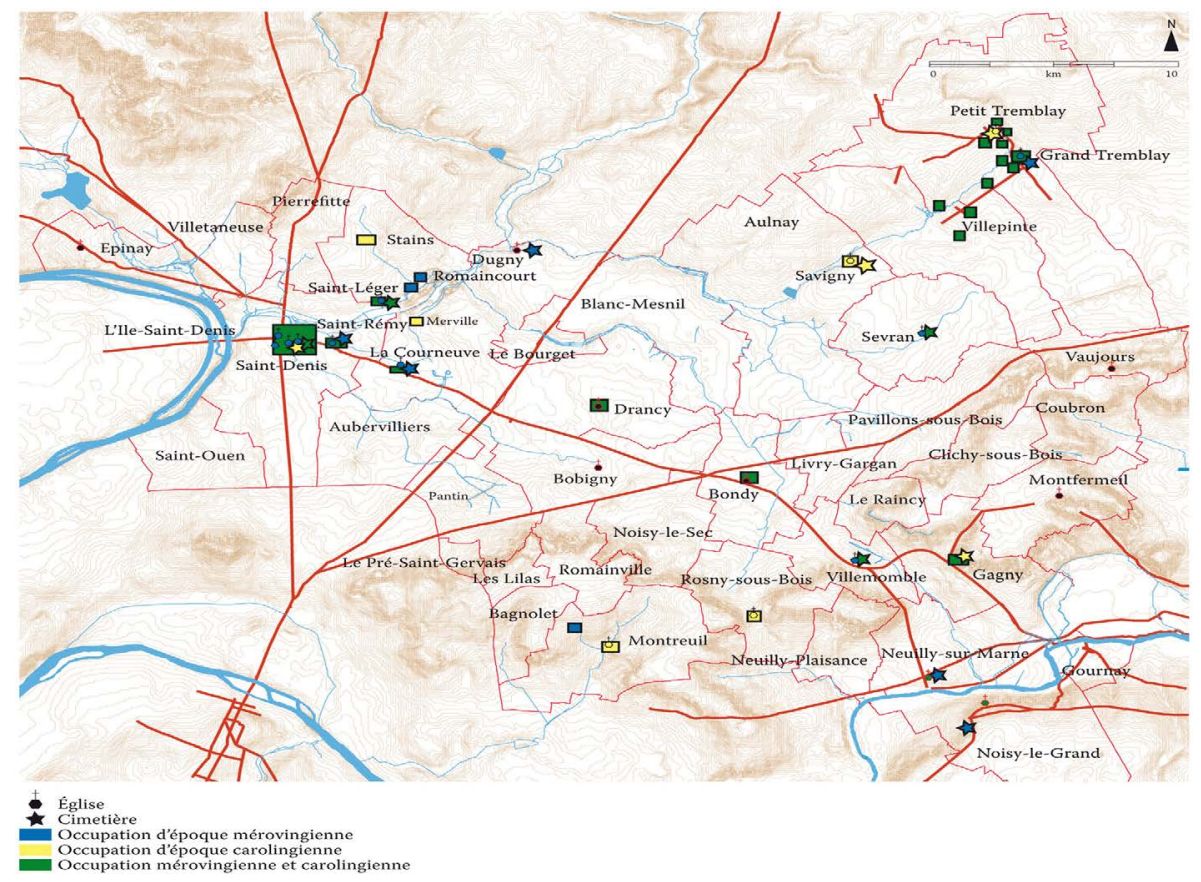

Source: Buissart; Lafarge; Le Forestier, 2012, p. 48.

\section{The Importance of Paris in the Merovingian Period and Beyond}

In the first place, considering the fact that the Church of the Holy Apostles and the Church of Saint Vincent held saint's relics and especially the bodies of the deceased Merovingian royal members and were both very close to the inhabited left bank of Paris, we can affirm that they greatly elevated the prestige of the city (Figure 3 ). This was also the case 
of the Church of St. Denis. Although it was $12 \mathrm{~km}$ away from Paris, this church was very associated with the city. It could be accessed by the road, it celebrated the first bishop of Paris (St. Denis) and also a great king who also lived very nearby (Dagobert I). The Church is also frequently associated with Paris and the events that happened there (GRÉGOIRE DE TOURS, 1999a, V, XXXII; FREDEGARIUS SCHOLASTICUS apud KRUSCH, 1888, IV, LIV) (Figure 4).

When the members of the Merovingian family died, there was a great procession to the Church that he or she chose as his graveyard. This procession was composed by other members of the family, the clergy and the inhabitants of the city. In the case of Paris, we have reference to the big procession of Clotilde, Clovis' wife, from Tours to the Church of the Holy Apostles at Paris and the processions of Clovis and Merovech (Chilperic's sons) to the Church of Saint Vincent. Besides the funerary processions, it is actually quite possible that there were processions to these Churches in the day of the saint's festival and even weekly processions organized by the bishop can be deduced from the example of Bishop Ragnemod (576-591) (GRÉGOIRE DE TOURS, 1999b, IX, VI). ${ }^{30}$ Furthermore, considering its closeness to the city, it is also possible that the inhabitants of Paris went frequently to all of these churches hoping for the miracles of the saints. According to Gregory of Tours, the tomb of Geneviève, for example, was already famous in Paris for the occurrence of healing miracles (GREGORY DE TOURS, 1988, 89).

In these three churches, there was a great number of colored marble columns. In the archaeological excavations at least one column of the Church of the Holy Apostles, three from the Church of SaintVincent and eleven from the Church of Saint-Denis were found (Figure 5) (VIEILLARD-TROIEKOUROFF, 1976b; BUSSON, 1998, p. 349-373). Besides these columns, as we have seen, each of the three churches had their own specificities (paintings in the Church of the Holy Apostles; mosaics in the Church of Saint Vincent; precious ornaments associated with St. Eligius in the Church of Saint-Denis). This is relevant because

${ }^{30}$ Gregory indicates, for example, that the tomb of Germanus was already famous for its miracles on the day of this saint's festival (GREGORY DE TOURS, 1988, 88). 
the importance of the light is already present for Christianity at least since the end of the first century AD. ${ }^{31}$ Therefore, the luxurious architecture and especially the interplay of the lights would certainly be dazzling and splendid because the colored marbles and/or the tesserae mosaics and/ or the precious stones reflected the light that came through the windows (or the candles at the nighttime). This certainly amazed its visitors and made the interior of the Church a divine and resplendent place that was considered worthy to be the House of God and the final resting place of the saints and those very close to them, the Merovingians buried right there.

FIGURE 5 - The capital (topmost member of a column) of one of the colored marble columns of the Church of Saint-Vincent found in the excavations.

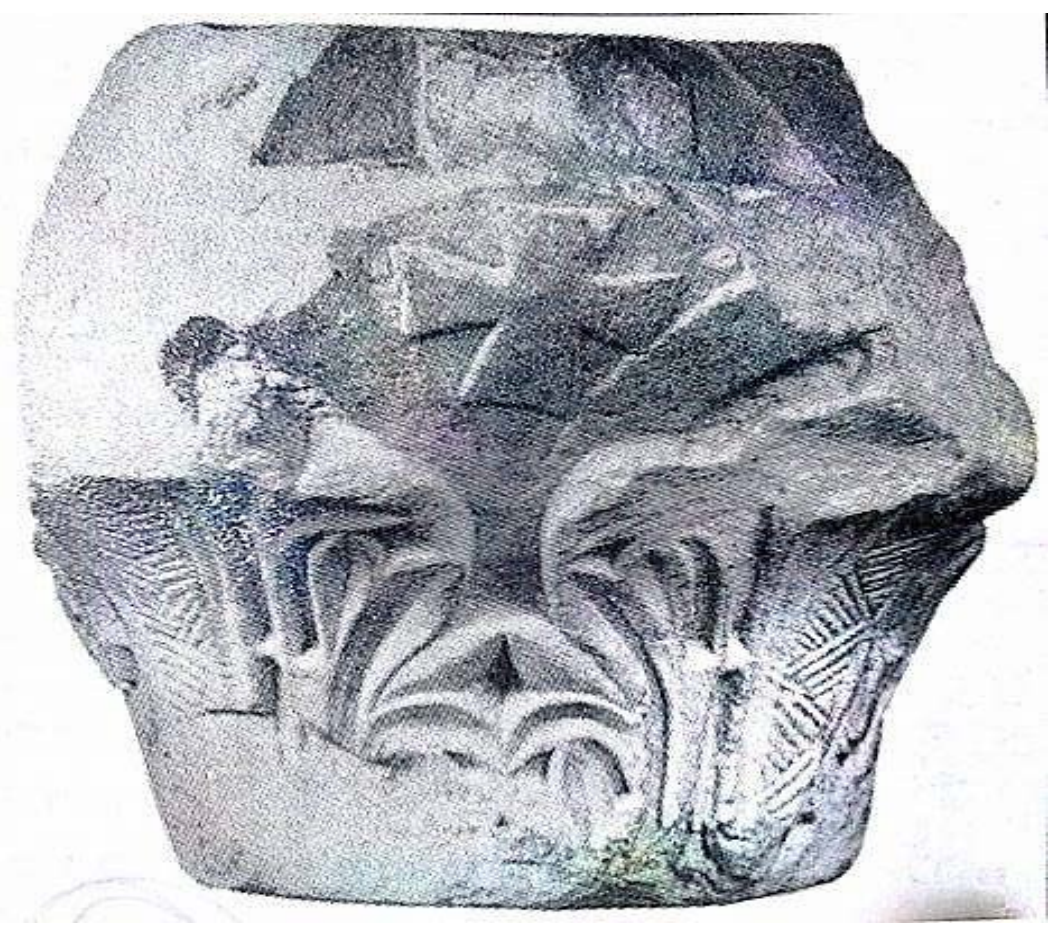

Source: Busson, 1998, p. 356.

31 "Again Jesus spoke to them, saying, 'I am the light of the world. Whoever follows me will not walk in darkness, but will have the light of life'." John 8: 12. 
Because of these facts, we can notice the growing importance of the churches of Paris and the city itself starting in the sixth century. After the death of Chlothar in 561, before a new division of Gaul was established, Chilperic I, one of his sons, already attempted to take over Paris. His brothers Sigebert I (561-575), Charibert (561-567) and Gontran (561-592) didn't accept this fact and united to expulse Chilperic. Charibert, the oldest of them, took possession of the city (GRÉGOIRE DE TOURS, 1999a, IV, XXII). When this last king died in 567, the three remaining brothers came to an agreement that no one could occupy the city without the consent of the other two, but even after this, Chilperic I still made this city his residence (GRÉGOIRE DE TOURS, 1999b, VI, XXVII). Once again, when Chilperic died in 584 there was a confrontation between Gontran and the son of Sigebert I, Childebert II (575-595), because of Paris (GRÉGOIRE DE TOURS, 1999b, VI, XLVI, VII, V). Gontran established his dominance and we can observe that he was very interested in Paris and lived there at some periods of his life (GRÉGOIRE DE TOURS, 1999b, IX, XIII; IX, XXXXII). Gontran was also responsible for the baptism of Chlothar II, son of Chilperic I, in Paris and as we have seen before, this last king also chose this city as his residence (GRÉGOIRE DE TOURS, 1999b, IX, XXVIII). Finally, writing in the period between the end of seventh century and the beginning of the eighth century, the author of the Life of Balthid, a Merovingian queen from the second half of the seventh century, mentions six seniors basilicas: the Church of the Holy Apostles, the Church of Saint-Vincent, the Church of Saint-Denis, the Church of Saint Medard, the Church of Saint Aignan and the Church of Saint Martin. ${ }^{32}$ These were the great holy places of all Gaul and as we demonstrated above, three of them were in Paris (FOUCRACE; GERBERDING, 1996, p. 110).

The Church of the Holy Apostles was certainly not the mausoleum of the Merovingian family as Clovis might have wanted it, however, the city of Paris chosen by him was a symbol of the Merovingian dynasty.

\footnotetext{
${ }^{32}$ The Church in which Clovis was buried is called either Church of the Holy Apostles or Church of Saint Peter by Gregory of Tours (VIEILLARD-TROIEKOUROFF, 1976a, p. 206).
} 
While, according to the information we have, kings of other cities chose to be buried in other spaces, it is probable that all the kings resident in Paris were buried in churches closely related to this city during the sixth and seventh centuries. ${ }^{33}$ Besides Clovis' memories and tomb, all the other royal tombs enhanced the churches in which they were located and consequently, the city of Paris was greatly highlighted. The churches, the kings and the city of Paris: all these elements were intrinsically interconnected. At the same time, the consolidation of the Merovingian's royal power was part of the process of Christianization of the city. The new religious buildings and the daily practices associated with them created the new identity of the city: a Christian and, consequently, Merovingian Paris.

Beyond the Merovingian period, perhaps the city retained some of its importance in the Carolingian period. Even though this Dynasty came from the Kingdom of Austrasia, Charles Martel (c. 690-741) and his son Pepin, the Short (751-768), still chose to be buried in the Church of St. Denis (ERLANDE-BRANDENBURG, 1975, p. 70-73). Afterward, Paris was the capital of the Capetian Dynasty since the reign of Henry I (1031-1060). Sohm (2007, p. 19-22) provided many reasons why this king chose Paris considering questions such as topography and military importance. Nevertheless, we consider that one motive was not explained. The fact that Henry I was the first Capetian King to be baptized in Reims and his choice of Paris doesn't seem to be coincidences. It looks like to us that, in a moment where the king of France was overshadowed by a series of local powers, Henry I chose Paris because of its memory and prestige associated with Clovis and all the other Merovingians buried there. ${ }^{34}$ Therefore, Clovis and the Merovingian dynasty were very

${ }^{33}$ There aren't many references to the locations of inhumation of the kings of other cities, but we have the examples of Sigebert I (king of Metz, buried in Soissons) and Gontran I (the only king buried in Chalon-sur-Saône) (GRÉGOIRE DE TOURS, 1999a, IV, LI; FREDEGARIUS SCHOLASTICUS apud KRUSCH, 1888, IV, XIV).

${ }^{34}$ For more about the Capetian renovatio of the Merovingian past see CLARK, 1997, p. 341-358. 
important to Henry's choice and consequently, they were crucial to the eventual elevation of Paris to the capital of the Modern State of France.

\section{References}

BOUDEAU, J. Devenir et place des thermes publics dans les castra du Bas-Empire du Nord-Ouest de la Gaule: étude de dix chefs-lieux de cité de Gaule Belgique et Lyonnaise. Revue Archéologique du Centre de la France, [S.l.], t. 50, 2011.

BOUET, A et al. Thermes et pratiques balnéaires dans le chef-lieu de cité des Parisii. Gallia, [S.l.], t. 65, p. 355-403, 2008. DOI: https://doi. org/10.3406/galia.2008.3348.

BROWN, P. The Rise of Western Christendom: Triumph and Diversity. Oxford: Willey-Blackwell, 2013.

BUISSART, C.; LAFARGE, I.; LE FORESTIER, C. Les habitats ruraux du haut Moyen Âge en Seine-Saint-Denis. État des lieux. Archéopages, [S.l.], n. 34, p. 48-57, 2012. DOI: https://doi.org/10.4000/ archeopages.394.

BUSSON, D. Paris. Carte Archéologique de la Gaule 75. Paris: Académie des Inscriptions et Belles-Lettres, 1998.

CÂNDIDO DA SILVA, M.; MAZETTO JUNIOR, M. A realeza nas fontes do período merovíngio (séculos VI-VIII). História Revista, Goiânia, v. 11, p. 89-119, 2006. DOI: https://doi.org/10.5216/hr.v11i1.10070.

CÂNDIDO DA SILVA. A realeza cristã na Alta Idade Média: os fundamentos da autoridade pública no período merovíngio (séculos V-VIII). São Paulo: Alameda, 2008.

CLARK, W. Defining National Historical Memory in Parisian Architecture (1130-1160). In: GAUTHIER, N.; GALINIÉ, H. (ed.). Grégoire de Tours et l'espace gaulois. Tours: Fédération pour l'édition de la Revue Archéologique du Centre de la France, 1997. p. 341-358.

DALY, W. M. Clovis: How Barbaric, How Pagan? Speculum, Chicago, v. 69, n. 3, p. 619-664, 1994. DOI: https://doi.org/10.2307/3040846.

DELMAIRE, R. L'aerarium impérial et son administration du IVe au VIe siècle. Rome: École Française de Rome, 1989. 
DÉRENS, J. Gislemar, Historien de Saint-Germain-des-Prés. Journal des Savants, Paris, n. 3, p. 228-232, 1972. DOI: https://doi.org/10.3406/ jds.1972.1270.

DEY, H. W. The Afterlife of the Roman City: Architecture and Ceremony in Late Antiquity And the Early Middle Ages. New York: Cambridge University Press, 2015. DOI: https://doi.org/10.1017/ CBO9781107706538.

DUCHESNE, L. Fastes Épiscopaux de l'Ancienne Gaule. L'Aquitaine et les Lyonnaise. Paris: Fontemoing et Cie, 1910. t. 2.

DUVAL, P. De Lutèce à Paris 1. Les origines de Paris. In:

Travaux sur la Gaule (1946-1986). Rome: École Française de Rome, 1989. p. 901-912.

EDMONDSON, J. Cities and Urban Life in the Western Provinces of the Roman Empire: 30 BCE-250 CE. In: POTTER, D. (ed.). A Companion to the Roman Empire. Oxford: Blackwell, 2006. p. 250-280. DOI: https:// doi.org/10.1002/9780470996942.ch14.

ERLANDE-BRANDENBURG, A. Le roi est mort: Étude sur les funérailles, les sépultures et les tombeaux des rois de France jusqu'à la fin du XIIIe siècle. Paris: Arts et Métiers Graphiques, 1975.

ERLANDE-BRANDENBURG, A; MÉREL-BRANDENBURG, A. B. Saint-Germain-des-Prés: An Mil. Paris: Picard, 2011.

FICHTL, S. Les Premières Villes au Nord des Alpes. In: GALINIÉ, H. (dir.). Tours Antique et Medieval: lieux de vie, temps de la ville. Revue Archéologique du Centre de la France, n. 30. Tours: FERACF, 2007, p. 323-325. (Supplément spécial de la collection "Recherches sur Tours").

FLEURY M.; LEPROUX, G-M. Histoire de Paris. École Pratique des Hautes Études, n. 16, p. 214-220, 2002. Section des sciences historiques et philologiques.

FOURACRE, P.; GERBERDING, R. Late Merovingian France: History and Hagiography. Manchester; New York: Manchester University Press, 1996. DOI: https://doi.org/10.7765/MMSO.47909.

FREITAS, E. C. Gregório de Tours e a Sociedade Cristã na Gália dos séculos Ve VI. Niterói: Eduff, 2015. 
GOFFART, W. The Narrators of Barbarian History (A.D. 550-800): Jordanes, Gregory of Tours, Bede, and Paul the Deacon. New Jersey: Princeton University Press, 1988.

GOODMAN, R. The Roman City and its periphery: From Rome to Gaul. Abingdon: University of Leeds; Routledge, 2007. DOI: https://doi. org/10.4324/9780203446256.

GREGORY OF TOURS. Glory of the Confessors. Translated by Raymond Van Dam. Liverpool: Liverpool University Press, 1988.

GRÉGOIRE DE TOURS. Histoire des Francs. Traduite du Latin par Robert Latouche. Paris: Les Belles Lettres, 1999a. t. I.

GRÉGOIRE DE TOURS. Histoire des Francs. Traduite du Latin par Robert Latouche. Paris: Les Belles Lettres, 1999b. t. II.

HEINZELMANN M. Gregory of Tours: History and Society in the Sixth Century. Cambridge: Cambridge University Press, 2001.

HURST, E. A. Mosaic Decoration in Byzantine Ravenna. [S. l.]: Saylor Academy, 2011.

JONES, C. Theodore Vacquer and the Archaeology of Modernity in Haussmann's Paris. Transactions of the Royal Historical Society, $6^{\text {th }}$ Series, v. 17 , p. $157-183,2007$. DOI: https://doi.org/10.1017/ S0080440107000576.

KRUSCH, B. (ed.). Monumenta Germaniae Historica. Hannover: Münchener Digitale Bibliothek, 1888.

LASTEYRIE, R. Cartulaire général de Paris; ou, Recueil de documents relatifs à l'histoire et à la topographie de Paris. Paris: Imprimerie Nationale, 1887. t. 1, p. 528-118.

LIBER Historiae Francorum. Edited and translated with an introduction by Bernard Bachrach. California: Coronado Press, 1973.

LIEBESCHUETZ, W. The End of the Ancient City. In: RICH, J. (ed.) The City in Late Antiquity. London; New York: Routledge, 1992. p. 1-49. LORANS, E. Ecclesia, basilica, monasterium: un vocabulaire à préciser. In: GALINIÉ, H. (dir.). Tours Antique et Medieval: lieux de vie, temps de la ville. Tours: FERACF, 2007. p. 284-285. 
MEDIEVAL Sourcebook: The Life of St. Eligius, 588-660. Translation and notes by Jo Ann McNamara. [S. l.]: Levison, 1997. Available at: https://sourcebooks.fordham.edu/basis/eligius.asp. Accessed in: 21 may 2019.

MODÉRAN, Y. L'Empire Romain Tardif: 235-395 ap. J-C. Paris: Ellipses, 2006.

PÉRIN, P. La reconstitution du costume d'Arégonde. Nouvelles propositions. Revue Archéologique de Picardie, n. 1-2, p. 69-75, 2009. DOI: https://doi.org/10.3406/pica.2009.3159.

PÉRIN, P.; RICHÉ, P. Dictionnaire des Francs: Les Temps Mérovingiens. Paris: Bartillat, 1996.

PESSOA, T. A. O poder legitimado através do espaço: o caso da Igreja Saint-Germain-de-Prés e a Realeza Merovíngia. Revista Cantareira, Noteroi, n. 25, p. 176-184, 2016.

PESSOA, T. A. O Rei como primeiro entre seus pares: a realeza merovíngia e a Igreja Saint-germain-des-Prés. Brathair, [S.l.], v. 17, n. 2 , p. $65-85,2017$.

POTTER, D. The Transformation of the Empire 235-337 c.e. In: POTTER, D. (ed.). A Companion to the Roman Empire. Oxford: Blackwell, 2006, p. 153-174. DOI: https://doi.org/10.1002/9780470996942.ch9.

POUPARDIN, R. Recueil des chartes de l'abbaye de Saint-Germain-desPrés des origines au début du XIIIe siècle. Paris: Champion, 1909. t. 1.

ROUCHE, M. Clovis. Paris: Fayard, 1996.

ROUCHE, M. Le changement de nom des chefs-lieux en Gaule au BasEmpire. In: ROUCHE, M. Le Choc des cultures: Romanité, Germanité, Chretienté durant la Haut Moyen Âge. Villeneuve-d'Ascq: Presses Universitaires du Septentrion, 2003. p. 13-35.

SOHM, A. Paris Capitale: quand, comment, pourquoi? In: WERNER, P.; BERTRAND, S. Paris, capitale des ducs de Bourgogne. Ostfildern: Thorbecke, 2007. (Beihefte der Francia, 64).

VIEILLARD-TROIEKOUROFF, M. Les chapiteaux de marbre du Haut Moyen-Age à Saint-Denis. Gesta, [S.l.], v. 15, n. 1/2, p. 105-112, 1976a. DOI: https://doi.org/10.2307/766756. 
VIEILLARD- TROIEKOUROFF, M. Les Monuments Religieux d'après les œuvres de Grégoire de Tours. Paris, Éditions Champion, 1976b.

WICKHAM, C. Framing the Early Middle Ages: Europe and Mediterranean, 400-800. New York: Oxford University Press, 2005. DOI: https://doi.org/10.1093/acprof:oso/9780199264490.001.0001.

WOOD, I. N. The Merovingian Kingdoms, 450-751. New York: Longman, 1994.

WOOLF, G. Becoming Roman: The Origins of Provincial Civilization in Gaul Cambridge: Cambridge University Press, 1998. DOI: https://doi. org/10.1017/CBO9780511518614.

WOOLF, G. Rethinking the Oppida. Oxford Journal of Archaeology, Oxford, v. 12, n. 2, p. 223-234, 1993. DOI: https://doi. org/10.1111/j.1468-0092.1993.tb00293.x.

WOOLF, G. Tales of the Barbarians: Ethnography and Empire in the Roman West. Chichester; Malden: Wiley-Blackwell, 2011. DOI: https:// doi.org/10.1002/9781444390810.

Recebido em: 19 de setembro de 2018.

Aprovado em: 13 de março de 2019. 